\title{
Effects of Absenteeism on Company Productivity, Efficiency, and Profitability
}

\author{
Mehmet C. Kocakülâh, Ph.D (Corresponding author) \\ College of Business Administration, University of Wisconsin - LaCrosse \\ 1725 State Street, La Crosse, WI 54601, USA \\ Tel: 608-785-6827 E-mail: mkocakulah@uwlax.edu
}

Timothy G. Bryan, CPA, CGMA, MSA

University of Southern Indiana, Romain College of Business

8600 University Blvd., Evansville, IN 47712, USA

Tel: 812-461-5386_E-mail: tgbryan@usi.edu

Stevie Lynch, MBA

Harding, Shymanski \& Co. P.S.C.

21 SE Third Street, Ste. 500, Evansville, IN, 47735, USA

Tel: 812-550-2086Ｅ-mail: srlynch@eagles.usi.edu

Received: October 31, 2017 Accepted: November 15, 2017

doi:10.5296/ber.v8i1.12395 URL: https://doi.org/10.5296/ber.v8i1.12395

\begin{abstract}
As the age of the 9 to 5 workday comes to close and employment situations become more and more complex with the rise of ever-growing technology, employers are experiencing ever-increasing costs of absenteeism. The purpose of this research paper is to answer the general question of how absenteeism affects a company's productivity, efficiency, and profitability. We seek to assist a company in understanding what absenteeism is, how to determine whether or not an absenteeism problem exists in the company, and how to recognize and eliminate issues related to absenteeism. Specific causes of absenteeism will be discussed, along with respective solutions that some companies are using to deal with these issues. We will conclude with a consideration of how companies can implement specific,
\end{abstract}


company-wide policies and organizational culture to attempt to combat absenteeism in the workplace.

Keywords: Absenteeism, Productivity, Profitability

\section{Introduction}

Recent estimates put unplanned or unscheduled absence costs at 8.7 percent of payroll, and employers are seeking the knowledge to better understand how increased absenteeism costs can affect the company's bottom line and what can be done to battle this issue (Wolters Kluwer, 2015). Absenteeism is an employee's intentional or habitual absence from work. While employers expect employees to miss a certain number of workdays each year, excessive absences can equate to decreased productivity and can have a major effect on company finances, morale, and other factors. These excessive unscheduled absences cost employers roughly $\$ 3,600$ per year for each hourly worker and $\$ 2,650$ each year for salaried employers (Forbes, 2013). According to a survey of 94,000 workers by the Gallup-Healthways Well-Being Index, the annual costs associated with absenteeism vary by industry, with the greatest loss occurring in professional occupations (Folger, 2017):

Table 1 .

\begin{tabular}{|l|l|}
\hline Occupation & Annual cost of lost productivity due to absenteeism (in billions) \\
\hline Professional & $\$ 24.2$ \\
\hline Managers/executives & $\$ 15.7$ \\
\hline Service workers & $\$ 8.5$ \\
\hline Clerical/office & $\$ 8.1$ \\
\hline Sales & $\$ 6.8$ \\
\hline School teachers (K-12) & $\$ 5.6$ \\
\hline Nurses & $\$ 3.6$ \\
\hline Transportation & $\$ 3.5$ \\
\hline Manufacturing/production & $\$ 2.8$ \\
\hline Business owners & $\$ 2.0$ \\
\hline Installation/repair & $\$ 1.5$ \\
\hline Construction/mining & $\$ 1.3$ \\
\hline Physicians & $\$ 0.25$ \\
\hline Farmers/foresters/fishers & $\$ 0.16$ \\
\hline
\end{tabular}

The Costs of Absenteeism Source: (Folger, 2017)

Absenteeism does not just mean missing a day of work, however. Partial shift absences consist of times when employees arrive late, leave early, and take longer breaks than scheduled in their day. While the occasional long lunch or late morning may not affect productivity, continued abuses decrease productivity and morale. Employees who see their coworkers leaving the job early or taking a long lunch feel that they're entitled to that additional time off too. As a matter of fact, partial shift loss has been shown to cause a $0.72 \%$ or more increase in payroll inflation alone (Synerion Workplace Management Solutions, 
2015).

Even when employees arrive at work, this does not necessarily mean that they will be fully functioning. A growing body of research indicates that the problem of workers being on the job but not producing at their usual output can cut individual productivity by one-third or more. This phenomenon known as "presenteeism" is most obviously associated with illness. As an example: employees arrive at work sick and not only work slower than normal but also hinder their ability to become well and spread the illness throughout the workplace. Presenteeism can also be used to classify any circumstance under which an employee is physically present but is not contributing in his or her normal capability.

When an employee is absent from work, this can have a number of generic effects on company output. While the only disadvantages to the employee of not returning to work are possible loss of pay and disciplinary actions, the coworker will immediately bare a large portion of the responsibility for the absence. Coworkers will be saddled with a large amount of work to keep up with the loss in company productivity, and this may lead to an increase in overtime and the cost that comes with it. The company may also experience an increase in accidents that could occur due to coworkers being confronted with unfamiliar machines or sets of job activities. This increase of labor for coworkers will affect the entire work group. Coordination problems will reach a climax, and productivity may decline if the replacement worker is less skilled than the absent worker (Atkin \& Goodman, 1984).

These effects of absenteeism can affect labor unions, the employee's family, and society as a whole. Through decreased productivity, everyone involved with the employee becomes less efficient and will see decreases in the bottom line due to the absence.

Fortunately, there are some specific measures that can be put in place before an absenteeism issue occurs that can help to guarantee heightened employee performance and attendance. The following section will explain what can be done by any company to prevent absenteeism from occurring.

\section{Research Question and Design}

2.1 Question: How does absenteeism affects a company's productivity, efficiency, and profitability?

2.2 Objective: The purpose of the research is to assist companies in:

- Understanding what absenteeism is,

- Determining whether an absenteeism problem exists in the company, and

- Recognizing and eliminating, or at least reducing, causes of absenteeism and the related costs

2.3 Source of Data: Secondary data from refereed journals, industry publications and industry web-sites

2.4 Research Importance: As is discussed in our paper, absenteeism creates significant costs for employers 
This paper discusses and compiles many of the causes of absenteeism that is scattered in the literature. Our research also compiles specific suggestions for reducing absenteeism due to a variety of causes. The paper focuses on application of theory and industry experience rather than developing or expanding theory.

\section{Preventing Workplace Absenteeism}

To prevent excessive and unnecessary absences for any reasons, an effective employee absence plan should be implemented to deal with attendance issues. The plan should clearly define expectations and outline disciplinary actions for employees that do not behave appropriately along with incentives for employees that do. The company can take preventative measures to reduce absenteeism through recruiting and training. Other effective actions companies can take to reduce absenteeism include positive reinforcement of solid attendance, and implementing flexible scheduling.

\subsection{Develop Absence Policy}

The first step in creating a system of controls to prevent absenteeism is to develop an airtight absence policy. In this way, employees will have a clear understanding of what the company expects. This will pave the way to implementing an organizational culture centered on exemplary attendance.

When establishing an absence policy, the company should be sure to set clear expectations. They should let employees know how much leeway they have before considering them late, and at what point they will be considered absent. In setting these expectations, the company must take time to clarify the difference between paid and unpaid time off. They should clearly explain policies for requesting time off, including any deadlines or restrictions. In addition, the terms and conditions for paid holidays, as well as military, religious, jury duty, and family and medical leave absences should be defined.

At this point in the control process, company policy for disciplinary actions should be created and documented so that every employee is fully aware of the rules. In addition, management should take the time to lead by example by arriving on time each day and only taking absences that are in line with company policy (Insperity, 2012).

\subsection{Proactive Recruitment}

An airtight absence policy will mean nothing, however, if employees are not competent or hard-working enough to follow company guidelines. Employees will be less likely to feel singled out and resent the attendance policy if it is consistent company-wide.

Employees should be hired based on high levels of competence and attendance, among other things. Using professional venues to attract employees is the best option when hoping to bring in candidates who will take company guidelines seriously. Once those employees are hired, the company should take plenty of time to train the employees on employer guidelines and to make sure that employees clearly understand what will be expected of them regarding absences (Miksen, 2015). 
In addition, communication should be kept up throughout the employee's time with the company to ensure that they are using absences positively. Any absence problems should be addressed and the company should be there to ask if increased absences could be beneficial to improving employee morale and decreasing presenteeism (Jackson, 2015).

\subsection{Positive Reinforcement}

In order to keep employees moving towards company goals after the initial hiring and training phase is complete, programs for positive reinforcement of attendance should be implemented. Four major types of positive reinforcement plans include financial incentive programs, recognition programs, lottery programs, and information feedback programs (Scott, Markham \& Robers, 1985):

- Financial incentive programs. These programs reward employees monetarily for excellent attendance. For example, at one company, a \$50 cash bonus was awarded at the end of the year for employees who had no absences. Employees who had one or two absences received a $\$ 25$ cash bonus. Companies can also pay employees for every sick or personal day that they do not take, or offer extra days for the next year for perfect attendance.

- Recognition programs. Some plants implement personal recognition events at the end of the year or quarter to recognize excellent service, while other companies award employees with few absences with cards signed by the manager, congratulating them, or with custom-designed, engraved jewelry commemorating the event and the company.

- Lottery programs. Lottery programs give employees with few or no absences the opportunity to enter a lottery in order to win a prize. Companies will be given lottery tickets based on the amount of absences accrued during the period, and if their name is drawn, they will be eligible to win a prize designated by their employer.

- Information feedback programs. In this type of program, no financial incentive is implemented, but employees are notified with each paycheck of their absence situation and how their level of attendance stacks up with that of other employees.

It appears that the most effective means of influencing employees is by implementing some combination of the above types of programs to incentivize employees to do what is right before disciplinary actions must be carried out in connection with rules.

\subsection{Flexible Scheduling}

Many companies have implemented some form of flexible scheduling to avoid much of the absenteeism costs that could occur down the road. Flexible scheduling can include flexible hours or flexible time schedules (an employee works from 10:00 a.m. to 6:00 p.m. instead of 9:00 a.m. to 5:00 p.m.), compressed workweeks (four 10-hour days instead of the typical five 8-hour shifts), part-time work, or job sharing (a structured form of part-time work) (HRCouncil.ca, 2015).

Most employers are a bit risk-averse when it comes to implementing a flexible scheduling policy up front. They fear that employees will abuse policies, they worry about the reactions 
of customers/clients to new worker policies, they fail to understand how they will be able to best supervise employees with flexible schedules, and they are concerned about the loss of productivity that could come from allowing employees to slip away from preset guidelines. In addition, could employees that are not in need of flexible scheduling feel that they are being Sloan Center on Aging and Work, 2015)?

While these issues will all need to be addressed when flexible scheduling policies are implemented, recent studies suggest that job flexibility can offer many benefits to both employers and employees, including improved job satisfaction, reduced absenteeism, greater commitment, and reduced turnover. For example, in a Boston College Center for Work \& Family study of six large companies, $70 \%$ of managers and $87 \%$ of employees reported that working a flexible arrangement had a positive or very positive impact on productivity; $65 \%$ of managers and $87 \%$ of employees reported that a flexible work arrangement had a positive or very positive impact on the quality of work; and $76 \%$ of managers and $80 \%$ of employees indicated that flexible work arrangements had positive effects on retention (MIT Center for Work, Personal, and Family Life, 2004).

Even if prevention initiatives are implemented, however, businesses have some mixture of absences, partial absences, and presenteeism within their workplace on a regular basis. Therefore, it is important for employers to understand whether or not their levels of absences are significant to generate further investigation and correction at increased levels of costs. The following section will seek to assist employers in determining whether or not an absence-tracking mechanism is required.

\section{Gathering Absenteeism Information}

The first step in solving an absenteeism problem in the workplace is to determine whether an issue exists. This first step brings quite a bit of difficulty with it, as most companies simply do not have a process in place to track rates of absenteeism in the workplace. Sure, every company has a method of gathering attendance data, but if an employee is simply clocking in or out of work every day, this is only providing data of when an employee is present or not. This data does not break down the reason for the absences to indicate whether the absence was due to an allowed holiday or family vacation, or whether the absence was in fact absenteeism and could have been avoided (Furnham, 2013).

The problem then is not that attendance data is not being collected, it is that attendance data is not being collected and analyzed properly. To correct this problem, managers should start by taking a look at attendance data in its purest form. Most managers will find that Monday is the most abused day of the week and January is the worst month for absences (Corbell, 2015). If this or other strange patterns of absences occur, combined with high rates of absence or high employee turnover, it is probably time for the company to consider a more in-depth means of dealing with absenteeism.

Human resources is the department that deals most closely with employees calling in, so it is important that the human resources department be prepared to ask the specific questions when an employee calls in. While certain laws and regulations protect employees from 
having to give out too much information, certain basic information can be reaped from the call-ins that can be used to better pinpoint absentee fluctuations. For example, the human resources department should make sure to make a clear definition in records between "partial absences" and "absences" to draw attention to this trend. In addition, differentiation between different types of absences, particularly between excused absences, medical or disability-related absences, and uncontrollable personal emergency absences can help the company to better distinguish what issues are at the forefront of its absenteeism problem (Winmark Corporation, 2015).

To ensure employee honesty during the call-in process, requests for proof of absence should be required as part of company policy. Doctor's notes, copies of obituaries, and mechanic receipts can all be valid forms of evidence that can help keep employee absences down and increase information collection to determine how to best solve problems.

Human resources should not be the only department involved in determining whether an absenteeism problem exists, however. Line managers should be trained to keep open conversations with employees who experience frequent absences or who appear to be exhibiting "presenteeism" at work in order to reap more information that can be utilized by the company. It is important that line managers be involved in the process to better understand the specific nature the company is experiencing absenteeism issues. The following section will discuss some of the major causes of absenteeism in the workplace.

\section{Causes of Absenteeism}

Once a program to track absenteeism has been put into use, it will be time to track the data and determine the major causes of absenteeism in the specific workplace. This section will analyze seven major causes of absenteeism that companies will more than likely discover and specific ways to battle each cause.

\subsection{Illness and Injury}

\subsubsection{Effects on Productivity, Efficiency, and Profitability}

The Integrated Benefits Institute, which represents major U.S. employers and business coalitions, says poor health costs the U.S. economy \$576 billion a year, according to new research. Of that amount, 39 percent, or \$227 billion is from "lost productivity," employee absenteeism due to illness or "presenteeism." Wage replacement costs $\$ 117$ billion from absence due to illness as well as workers compensation and both short- and long-term disability. Meanwhile, another $\$ 232$ billion of poor health costs come from medical treatment and pharmacy related costs.

In 2003, an estimated 18 million adults aged 19 to 64 were not working and had a disability or chronic disease, or were not working because of health reasons. Sixty-nine million workers reported missing days due to illness, for a total of 407 million days of lost time at work. Fifty-five million workers reported a time when they were unable to concentrate at work because of their own illness or that of a family member, accounting for another 478 million days (Collins, Davis, Doty, Ho, and Holmgren, 2005). 


\subsubsection{Specific Cures}

A number of methods have been put into place in order to possibly find a cure for absenteeism related to illness. The most popular of these methods is to require proof of illness by employees. However, the extent to which an employer may inquire into the nature of and reasons for an employee's absence from the workplace is a delicate issue. The concepts of an employee's privacy and an employer's need for information affecting the workplace often come into conflict. In addition, unions will often strongly object to any efforts by management to inquire more deeply into the nature of an employee's illness (Benefits Interface, 2014).

While requiring proof of illness could curb incidents of employees abusing sick days, this does not solve the issue of the inability of employees to perform substantially due to actual sickness. Many companies have recently taken it into their own hands to provide wellness programs that encourage employee health. Research recently published by executive search firm Humanity Search and Select states that a 5\% increase in productivity through proper wellness programs can determine success or failure (The Skills Portal, 2013). While wellness programs serve the major purpose of bringing education and awareness to health issues, they can save costs largely down the road by enabling faster recognition of medical symptoms, which can lead to quicker recovery and lower company medical costs.

Small steps can be taken along the way to prevent the spread of diseases throughout the workplace as well. Hand washing is the most effective way to prevent the spread of communicable disease, and elementary schools have recently begun to recognize the benefits of including alcohol-free instant hand sanitizers throughout classrooms. A recent study revealed that after just 5 weeks, students using the active product were 33\% less likely to have been absent because of illness (White, 2014).

\subsection{Burnout: Work-Related Stress, Low Morale, and Disengagement}

\subsubsection{Effects on Productivity, Efficiency, and Profitability}

A recent study by Canada Life Group Insurance showed that one in six employees who have falsely called in ill said that they had done so because they were tired. In addition, 12 percent stated that they needed time off due to work-related stress but did not want to admit it (Pay and Benefits, 2014). The most widely accepted conceptualization of job burnout identifies it as a multifaceted phenomenon with three primary components (Kulik \& Parker, 1995):

- Emotional exhaustion, or the depletion of one's emotional resources and feelings of being overextended

- Depersonalization, or when one develops negative or callous attitudes about the clients or patients with whom one works and views or treats them as objects

- Feelings of low personal accomplishment, or the individual experiences a decline in his or her feelings of competence and successful achievement in working with people

Burnout adversely impacts the financial performance of businesses by taking the "life" out of the "high flyers" of the company: 
- Reducing the engagement, commitment, and retention of high flyers

- Reducing the productivity, health, and well-being of high flyers

- Presenting substantial risk management issues for the brand, market image and public reputation of the organization

- Jeopardizing the talent pipeline and succession management

A 2005 U.K. study showed revealed that burnout is having a direct impact on the bottom line and the corporate reputation of $15 \%$ of U.K. businesses, with more than a third of employers reporting a decline in productivity and the majority seeing an increase in the number of sick days being taken (Casserley \& Megginson, 2009).

\subsubsection{Specific Cures}

It appears that the best way to keep employees motivated at work and in good spirits is to encompass a plan of communication, motivation, and leadership. Communication with employees should be established by holding regular staff meetings, emphasizing positives and downplaying negatives, recognizing and acknowledging their work, and clarifying expectations and job requirements. Motivation should be carried out by finding out what motivates employees, showing appreciation, encouraging stress relievers, fresh air, and vacation days, and increasing compensation. Employees can be led by improving leadership skills, sending employees to training, and assigning tasks accordingly (Slide, 2015).

Interestingly enough, in today's age of technological closeness, a leading cause of employee stress and burnout has been the incessant intertwining of work and home life through technology. Devices have caused employees to become 24/7 intravenous hookups to their jobs, with e-mails and phone calls buzzing in well after they have clocked out for the day. To keep employees from becoming disengaged with the company's goals, some employees are going the extra mile to keep a safe distance between employee home and work life. For example, Volkswagen company recently pledged to deactivate e-mails on German staff BlackBerries during non-office hours. In a bid to combat employee burnout, staff at Volkswagen will be limited to only receiving emails on their devices from half an hour before they start work until half an hour after they leave for the day, and will be in blackout mode the rest of the time (Knowledge Wharton, 2012).

\subsection{Depression}

\subsubsection{Effects on Productivity, Efficiency, and Profitability}

In a given year, 18.8 million Americans (9.5\% of the adult population) will suffer from a depressive illness (Boehm, Buttar, Valenstein, Vijan, \& Zeber, 2001). Approximately $80 \%$ of this population will suffer some level of functional impairment because of their illness (Brody \& Pratt, 2008). In a 3-month period, patients with depression miss an average of 4.8 workdays and suffer 11.5 days of reduced productivity (Boehm, Buttar, Valenstein, Vijan, \& Zeber, 2001).

Depression tops the list of health-related productivity costs in the workplace. The annual cost of depression is estimated at $\$ 44$ billion in lost productivity to American companies 
according to the National Institute of Mental Health. It can thwart an employee's ability to concentrate, be effective, and stay healthy enough to hold down a job (Martin, 2012).

In addition, research shows that rates of depression vary by occupation and industry type. Among full-time workers aged 18 to 64 years, the highest rates of workers experiencing a major depressive episode in 2007 were found in the personal care and service occupations and the food preparation and serving related occupations. Occupations with the lowest rates of workers experiencing a major depressive episode were engineering, architecture, and surveying; life, physical, and social science; and installation, maintenance, and repair (Substance Abuse and Mental Health Services Administration, Office of Applied Studies, 2007).

\subsubsection{Specific Cures}

A number of studies of a diverse group of occupations have identified several job stressors that may be associated with depression, including high job demands, low job control, and lack of social support in the workplace. However, depression is a complex condition, and changes in the workplace environment will not necessarily decrease rates of depression drastically throughout the workplace. In order to ensure that employees are receiving all of the care necessary regarding this phenomenon, it is important for employers to both be proactive and reactive. Employers should be proactive in creating a workplace that eliminates risks of depression caused by stress, bullying or harassment, or other workplace issues. Employers should be reactive in responding to employees already suffering from depression by providing assistance such as depression recognition screenings, employee assistance programs, supervisors trained in depression recognition, and ensuring workers' access to needed psychiatric services (Centers for Disease Control and Prevention, 2014).

\subsection{Bullying and Harassment}

\subsubsection{Effects on Productivity, Efficiency, and Profitability}

Recently much attention has been given to the concept of bullying in absenteeism. While bullying has long been a reason for absenteeism regarding school children, this phenomenon has been ignored as a cause for workplace absenteeism until recently. A recent survey of 100,000 public servants in Australia found that 17 percent of employees indicated that they had been subjected to harassment or bullying in their workplace in the last 12 months. A further 21 percent of employees said that they had witnessed another employee being subjected to what they perceived as bullying or harassment in the same time period. (Pianegonda, 2014).

Why does this matter? Bullying and harassment affect productivity. Employees who feel undermined at work are more likely to be stressed and to miss work for health reasons. Employees are significantly less creative when they are bullied at work, and one study even found that just watching someone get bullied at work is linked to depressive symptoms (Lebowitz, 2013). 


\subsubsection{Specific Cures}

Proactive employers have addressed behavioral issues through Code of Conduct policies intended to eradicate outrageous, disrespectful, and bullish behavior toward coworkers. Nonetheless, evidence indicates that these efforts have failed to produce the employer reaction and intervention expected by the affected workforce (Employment Practices Solutions, 2011). Sharpe Health and Safety Assessment \& Prevention outlines the following employer initiatives that should be utilized to help stop workplace bullying and harassment:

- Educate all staff on the subtleties of bullying

- Ensure anti-bullying policy is current

- Inform HR professionals how to deal with complaints of bullying

- Tutor managers how to recognize bullying

- Provide information on support groups, web sites, forums, etc.

- Accept responsibility to act once alerted to bullying

\subsection{Maternity Leave and Childcare}

\subsubsection{Effects on Productivity, Efficiency, and Profitability}

A quarter of all women in the U.S. return to work fewer than 10 days after giving birth, decreasing productivity by giving them less time to bond with their children, making breast-feeding more difficult, and increasing their risk of post-partum depression. According to the American Academy of Pediatrics, suboptimal breast-feeding causes higher rates of infant illness and hospitalization that cost billions of dollars annually (Wojcicki, 2014).

Paid maternity leave is also good for business. After California instituted paid medical leave, a survey in 2011 by the Center for Economic and Policy Research found that $91 \%$ of employers said the policy either boosted profits or had no effect. They also noted improved productivity, higher morale and reduced turnover. When Google recently increased paid maternity leave to 18 from 12 weeks in 2007, the rate at which new moms left Google fell by $50 \%$ (Wojcicki, 2014).

The U.S. is one of just two countries from a recent 185-country study where new mothers aren't guaranteed paid leave. Right now, just $12 \%$ of U.S. workers in private industry receive paid family leave benefits that allow them to take time off after giving birth or to care for a sick family member without giving up a paycheck. In the absence of formal maternity or family leave policies, the vast majority of women make do with a combination of sick days, vacation time, and unpaid leave so they can spend some time at home after having a baby (Elliot, 2015).

While most would think that there must be some underlying reason why the United States would deny so many women maternity leave, the methodology is not wholesome. Most people believe that the U.S. has simply not made a change due to the fact that the country deals with finance and parenthood individually, with each family fending for themselves. This comes in direct correlation with the Reagan administration's right wing frightening of moderates by explaining that maternity leave simply meant "more big taxes by big 
government (Liebelson, 2014)." In fact, according to the National Partnership for Women and Families, the payroll tax costs employees less than $\$ 2.25$ per month (London, 2014)

The birth of a child is just the start of absenteeism issues related to children. A 2011 survey of nearly 1,500 households by the Academic Pediatric profession found that nearly $46 \%$ reported that they had experienced childcare-related employment changes, while many others reported absences from work and changes to the schedule as being necessary to maintain their household. Single-parent households reported childcare needs at nearly twice the level of typical two-parent households. In addition, having a child with behavioral problems or a serious chronic health condition was associated with double to triple odds of many childcare-related employment problems, signaling even more absenteeism issues (Montes \& Halterman, 2011).

Childcare breakdowns leading to employee absences cost businesses $\$ 3$ billion annually in the United States (Friedman, 1986). In addition, drains on productivity of not providing childcare can be immense. When employee reliability due to childcare needs goes down the drain, so does company morale and efficiency.

\subsubsection{Specific Cures}

Maternity leave is a hot-button topic at the moment in the United States, and while it is still not mandatory for U.S. corporations to provide maternity leave to workers, there is much that can be done to help combat this issue right away. If a company does not have the assets to simply offer paid maternity leave, they should consider other ways to make new parents comfortable maneuvering between home and work life. That means small companies should consider letting new parents work from home, complete tasks outside of normal working hours, or even pool with other local businesses to offer childcare (Clark, 2014).

The best way to keep employees with children motivated while on the job is to provide child care for employees. That can come from offering on-site childcare or daycare center scholarships, helping employees arrange babysitter co-ops, offering flex-time or telecommuting programs, or starting partnerships with child-care providers that give staff discounts on memberships and access to nationwide databases of caregivers. One study reported substantial benefits from offering childcare services (Marcelo, 2009):

- 62 percent of respondents reported higher morale

- 54 percent reported reduced absenteeism

- 52 percent reported increased productivity

- 37 percent reported lower turnover

While some employers may feel that offering such benefits to working mothers is extraneous, they should keep in mind that over $75 \%$ of women who are employed have school-age children, and the average American mother misses nine days of work tending to children. This totals up to nearly $\$ 3$ billion in annual childcare costs in the United States. Since socioeconomic forecasts predict that women will outnumber men in the workforce within the next decade, it is more than necessary for today's corporations to offer some form of assistance for working moms (Programs for Parents, Inc., 2011). 


\subsection{Eldercare}

\subsubsection{Effects on Productivity, Efficiency, and Profitability}

Americans are living longer and the number of older adults is steadily increasing. This phenomenon will largely impact the causes of absenteeism, as one third of caregivers are now in the workforce (Cooper, 2010). Unfortunately, social stigmas cause employers to typically associate eldercare as something quite different from childcare--while employers are quick to check in regarding the well-being of employees' children, they are not as adept at recognizing signs of stress in dealing with elder relatives. While time away from work to care for elders is definitely needed by employees, the high costs of eldercare is also beginning to place stress on employees that can affect workplace productivity. Studies have shown that employees caring for older adults are $20 \%$ more likely to see a physician than employees who are not obligated to care for their elderly (Woldt, 2015).

Eldercare can effect productivity specifically through its disallowance of employees to put their all into their work. Nearly seven in ten (68 percent) of caregivers report making work accommodations because of caregiving. These adjustment include arriving late/leaving early or taking time off, cutting back on work hours, changing jobs, or stopping work entirely. From a profitability standpoint, eldercare costs U.S. businesses up to an estimated $\$ 33.6$ billion per year in lost productivity from full-time working caregivers. In one study, employers found that they paid about 8 percent more for the health care of caregiver employees compared to non-caregivers (Choula and Feinberg, 2012).

\subsubsection{Specific Cures}

To attempt to solve the growing dilemma of eldercare absenteeism, employers are beginning to view eldercare as the "new" childcare. Employees are finding many new opportunities in the workplace to find assistance, including support groups held onsite for caregivers, expanded employee assistance programs, referrals to organizations that provide assistance, and educational and informational programs held onsite to care for loved ones. While all of these programs appear to be working in keeping employee morale and attendance up in regards to eldercare, the most radical (and potentially the most successful) of these cures is to provide access to eldercare managers as an employee benefit. The costs to the company of providing these benefits are quite small if employees are able to arrive at work and produce satisfactory outputs because they know that their elders are in good hands (Roberts, 2015).

\subsection{Employee Turnover and Job Hunting}

\subsubsection{Effects on Productivity, Efficiency, and Profitability}

It is obvious that employee turnover can be a significant cost to employees regarding both productivity and profitability. The Center for American Progress (CAP) found that for all jobs earning less than $\$ 50,000$ per year, or more than 40 percent of U.S. jobs, the average cost of replacing an employee amounts to fully 20 percent of the person's annual salary. Since the average man will hold 11.4 jobs and the average woman will hold 10.7 jobs in their lifetime, this can amount to significant costs. In addition, employees who leave the company can cause 
a trail of unrest in their wake. Remaining employees often have to absorb additional duties and grow increasingly insecure about their own jobs (Moran, 2013).

Employee absenteeism due to job hunting may be a more difficult issue to address, as employees will typically be much more conservative regarding information about their job search process. Employees will not be quick to volunteer information that they are seeking employment elsewhere, and most will not consider resignation until another position has been secured. However, there are some obvious signs that can help alert employers to unhappy employees seeking greener pastures. Is an employee demonstrating a noticeable change in attitude, with less communication to management? Are they taking longer lunch breaks and an abundance of personal phone calls? Are they showing up at the office dressed to the nines with portfolio in hand? If these factors are causing increased rates of absence, action must be taken to find the root of the issue and convince the employee to stay on board (Robert Half, 2015).

All of these behaviors can, of course, lead to excessive losses in company productivity. If employees are using work time to take personal phone calls or are cutting out early to attend interviews, this can of course affect profit margins. The American Management Association found that declining employee loyalty is thought to cause low morale (84\%), high turnover $(80 \%)$, disengagement $(80 \%)$, growing distrust $(76 \%)$, and lack of team spirit $(73 \%)$. All of this will no doubt effect productivity and efficiency throughout the workplace.

\subsubsection{Specific Cures}

The first mistake that many employers make in trying to keep employees on board is to implement programs that make employees happy. Employers try to add lifestyle-improving perks such as more flexible scheduling and small gifts or cash prizes in order to keep key employees in check. Interestingly enough, however, most employees are job hunting not because they are unhappy at work. As a matter of fact, a recent study found that while people were $8 \%$ more likely to job hunt in 2014 than they were in 2013, they were actually $23 \%$ happier with their current jobs than they had been in 2013 (Stillman, 2014).

Strauss \& Howe's The Fourth Turning and Dr. Gustavo Grodnitzky's "Ready or Not, Here They Come!" both try to seek to understand these strange behaviors in job hunting by understanding the four recurring generational types: Civic, Adaptive, Idealist, and Reactive. These four generational types have continued to rotate for hundreds of years.

Table 2.

\begin{tabular}{|c|c|c|c|}
\hline Years & Era Type & Generation Type & Generation \\
\hline $1901-1924$ & Unraveling & Civic & G.I. \\
\hline $1925-1945$ & Crisis & Adaptive & Silent \\
\hline $1946-1964$ & High & Idealist & Boomer \\
\hline $1965-1981$ & Awakening & Reactive & Gen X \\
\hline $1982-2000$ & Unraveling & Civic & Gen Y \\
\hline $2001-200 ? ?$ & Crisis & Adaptive & Gen Z? \\
\hline
\end{tabular}


Grodnitsky, G.: Ready or Not, Here They Come! Personal Communication by D. Goodman, 2015

The forthcoming generation, the Millennials (1982 - 2000), is a civic generation. While the current generation of Boomers are interested in money and controlling time at work, Millennials are interested in relationships, causes, and blended life. While Boomers don't chat, Millennials want constant feedback. While Boomers are stoic, Millennials need a strong bond with their boss (D. Goodman, personal communication, March 16, 2015).

So how can an employer keep employees from job hunting on company time, or ultimately leaving the company empty-handed? They can attack this issue by trying to create bonds with Millennials by creating a culture that makes employees feel like home. This culture can be created through providing high levels of praise to staff accomplishments, and recognizing birthdays, anniversaries, and special occasions. With the gap in interests between Boomers and Millennials, some employers are finding it more cost-efficient and effective to have employees teach each other. The bonds that employees will share with each other will help keep them focused on where they are and enable them to establish clear career paths that benefit all parties (Marker, 2004).

\section{Curing Absenteeism}

With all of the many different causes of absenteeism, it is impossible for a company to target each cause specifically and implement programs that will satisfactorily lower rates of absenteeism at reasonable costs. Therefore, determining whether or not to fix the absenteeism issue will depend on how the company wants to best direct their resources and energy. In addition to a detailed cost-benefit analysis, there is a simple formula to help determine whether the costs of solving absenteeism issues are worth the benefits that can be reaped. For a given company, simply divide the employee's salary plus average employer costs by working days (in a calendar year) to determine the average cost of a sick day for an employee. In the following example, we will consider an employee salary of $\$ 40,000,30 \%$ employer costs, and 240 working days:

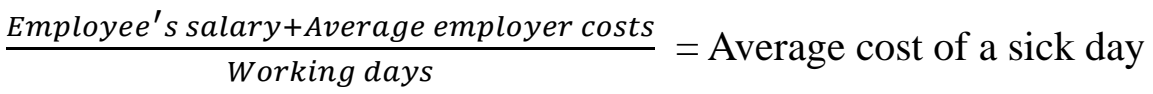

$\frac{\$ 40,000+\$ 12,000}{240 \text { days }}=\$ 217$ per day

Now suppose that the company in question experiences absenteeism at the U.S. average rate of $2.5 \%$, or approximately 4 employees out of every 150 (Wellworks for You, 2015). The absenteeism rate of $2.5 \%$ or 4 employees per day would result in a cost of $\$ 868$ per day ( $\$ 217$ $\times 4$ employees) and an annual cost of $\$ 208,000$ per year $(\$ 868 \times 240$ working days).

What does this formula show? It shows that most companies will more than likely find that their costs of absenteeism are significantly high enough to merit an investment in an absenteeism management system to attempt to lower these costs. 


\section{Conclusion}

Absenteeism is clearly an important issue that is costing businesses in the United States billions of dollars every year. The problem with absenteeism is that most companies do not understand the negative effects of the phenomenon on productivity, efficiency, and profitability.

Some controls, like developing a proficient employee absence policy or proactively recruiting and training employees, can help to lessen the effects of absenteeism in the workplace. However, the best methods of putting an end to high absenteeism costs are to develop an understanding of where problems are occurring and how to stop absence issues on a case-by-case basis. To do this, employers will have to pay close attention to attendance records to understand whether or not employees are using time off effectively.

Employers can see absenteeism issues under a wide variety of categories. The most prevalent reasons for absence issues include illness and injury, burnout, depression, bullying and harassment, maternity leave and childcare, eldercare, and job hunting. If employers can implement causes that directly target company issues with absenteeism, they will be in good shape. However, the costs and time consumption of implementing case-by-case cures should be analyzed in order to determine whether or not the benefits are worth the fixes.

The least expensive and best practice for significantly lowering unnecessary employee absences is to implement systems of positive reinforcement, flexible scheduling, and disciplinary proceedings to deal with excessive absences. At any rate, solving company absence issues will allow employers to receive greater employee efficiency and lower the costs of losing out on that extra day of work and increase company productivity and profitability.

\section{References}

Atkin, R., \& Goodman, P. (1984). Effects of absenteeism on individuals and organizations. Retrieved from Carnegie Mellon University. Website:

http://repository.cmu.edu/cgi/viewcontent.cgi?article=1836\&context=tepper

Benefits Interface, Inc. (2014). Guidelines for absenteeism control. Retrieved from: http://www.benefits.org/optimize/risk-sharing/attendance-management?showall=\&start=2

Boehm, K., Buttar, A., Valenstein, M., Vijan, S., \& Zeber, J. E. (2001). The cost-utility of screening for depression in primary care. Annals of Internal Medicine, 134(5), 345-360. https://doi.org/10.7326/0003-4819-134-5-200103060-00007

Boston College, Sloan Center on Aging and Work. (2015). Barriers to workplace flexibility $(W F)$. Retrieved from: http://workplaceflexibility.bc.edu/Barriers

Brody, D. J., \& Pratt, L. A. (2008). Depression in the United States household population, 2005-2006. Center for Disease Control and Prevention, National Center for Health Statistics. (NCHS Data Brief No. 7; 2008). Retrieved from:

http://www.cdc.gov/nchs/data/databriefs/db07.htm\#ref08 


\section{Macrothink}

Business and Economic Research ISSN 2162-4860 2018, Vol. 8, No. 1

Carter, B. (2016, November 8). Two years of employee engagement and loyalty stats, summarized [Web log post]. Retrieved from:

https://blog.accessperks.com/two-years-of-employee-engagement-loyalty-stats-summarized.

Casserley, T., \& Megginson, D. (2009). Learning from burnout. Great Britain:

Butterworth-Heinemann

Centers for Disease Control and Prevention. (2014). Depression. Retrieved from:

http://www.cdc.gov/workplacehealthpromotion/evaluation/topics/depression.html

Choula, R., \& Feinberg, L. (2012). Understanding the impact of family caregiving on work. AARP Public Policy Institute. Retrieved from:

http://www.aarp.org/content/dam/aarp/research/public_policy_institute/ltc/2012/understandin g-impact-family-caregiving-work-AARP-ppi-ltc.pdf

Clark, P. (2014, October). What small businesses get wrong about maternity leave. Bloomberg Businessweek. Retrieved from:

http://www.bloomberg.com/bw/articles/2014-10-21/maternity-leave-why-small-businesses-sh ould-offer-benefits

Collins, S., Davis, K., Doty, M., Ho, A., \& Holmgren, A. (2005). Health and productivity among U.S. workers. The Commonwealth Fund. Retrieved from:

http://www.allkidscovered.com/assets/cover_856_davis_hlt_productivity_usworkers.pdf

Cooper, C. (2010, September). Absenteeism in the workplace caused by eldercare needs and concerns. [Web log post]. Retrieved from:

http://www.chriscooper.com/resources/eldercare-articles/120-absenteeism-in-the-workplace-c aused-by-eldercare-needs-and-concerns.html

Elliot, M. (2015, March 23). The problems with maternity leave in America. Personal Finance Cheat Sheet. [Web log post] Retrieved from:

http://www.cheatsheet.com/personal-finance/the-real-cost-of-americas-poor-maternity-leavepolicies.html/?a=viewall

Employment Practices Solutions. (2011). Workplace bullying: U.S. employers' progress on this epidemic problem. (January 1, 2011). Retrieved from:

http://www.epspros.com/NewsResources/Newsletters?find=12205

Folger, J. (2017). The causes and costs of absenteeism. Investopedia. (November 6, 2017). Retrieved from:

http://www.investopedia.com/articles/personal-finance/070513/causes-and-costs-absenteeism .asp

Friedman, D. E. (1986, Mar). Child care for employees' kids. Harvard Business Review, 64, 28. Retrieved from

https://login.lib-proxy.usi.edu/login?url=https://search.proquest.com/docview/227851593?acc ountid=14752

Furnham, A. (2013, October 24). Absence analytics: How to measure absenteeism at work. 
Psychology Today. [Web log post] Retrieved from:

https://www.psychologytoday.com/blog/sideways-view/201310/absence-analytics-how-meas ure-absenteeism-work

Hemp, P. (2004, 10). Presenteeism: At work - but out of it. Harvard Business Review, 82, 49-58. Retrieved from

https://login.lib-proxy.usi.edu/login?url=https://search.proquest.com/docview/227837576?acc ountid=14752

Hrcouncil.ca. (2015). Workplaces that work: Flexible work arrangements. Retrieved from: http://hrcouncil.ca/hr-toolkit/workplaces-flexible.cfm

Insperity. (2012). 5 tips for creating an airtight time and attendance policy. Retrieved from: http://www.insperity.com/blog/5-tips-for-creating-an-airtight-time-and-attendance-policy

Jackson, G. (2015). 5 ways to cure absenteeism. Retrieved from:

http://learnthat.com/5-ways-to-cure-absenteeism/

Japsen, B. (2012, September 12). U.S. workforce illness costs $\$ 576$ B annually from sick days to workers compensation. Forbes. Retrieved from:

http://www.forbes.com/sites/brucejapsen/2012/09/12/u-s-workforce-illness-costs-576b-annua lly-from-sick-days-to-workers-compensation/

Knowledge Wharton. (2012, February 19). Employee burnout is a fact. Here's how to fix it. [Web log post]. Retrieved from:

http://www.thefiscaltimes.com/Articles/2012/02/19/Employee-Burnout-Is-a-Fact-Heres-How -to-Fix-It

Kulik, J., \& Parker, P. (1995). Burnout, self- and supervisor-rated job performance, and absenteeism among nurses. Journal of Behavioral Medicine, 18(6).

https://doi.org/10.1007/BF01857897

Lebowitz, S. (2013, October 3). Bullies vs. BFFS: Why hostile workplaces are destroying productivity. [Web log post]. Retrieved from:

http://greatist.com/happiness/workplace-bullying

Liebelson, D. (2014, June 27). How America ended up with the worst maternity leave laws on Earth. The Week. Retrieved from:

http://theweek.com/articles/445827/how-america-ended-worst-maternity-leave-laws-earth

London, W., C. (2014, February 26). Baby steps. The Economist. Retrieved from:

http://www.economist.com/blogs/freeexchange/2014/02/maternity-leave

Marcelo, S. (2009, March 30). Child care solutions to absenteeism. HR.com. Retrieved from: http://www.hr.com/SITEFORUM?\&t=/Default/gateway\&i=1116423256281\&application=blo g\&elementID=1238449140453\&xref=https\%3A//www.google.com/

Marker, A. (2004, October 7). Low-cost steps to keep employees from job hunting. Water Quality Products. Retrieved from: 
http://www.wqpmag.com/low-cost-steps-keep-employees-job-hunting

Martin, J. (2012, October 23). Tackling depression at work as a productivity strategy. Forbes. Retrieved from:

http://www.forbes.com/sites/work-in-progress/2012/10/23/tackling-depression-at-work-as-a-p roductivity-strategy/

Miksen, C. (2015). How to recruit and train competent employees. Chron. Retrieved from: http://smallbusiness.chron.com/recruit-train-competent-employees-21675.html

MIT Center for Work, Family, and Personal Life. (2004). A guide to job flexibility at MIT: Tools for employees and supervisors considering flexible work arrangements. Retrieved from: http://hrweb.mit.edu/system/files/all/worklife/flexible_work_arrangements.pdf

Montes, G., \& Halterman, J. (2011). The impact of child care problems on employment: Findings from a national survey of US parents. Academic Pediatrics, 11(1), 80.

https://doi.org/10.1016/j.acap.2010.11.005

Moran, G. (2013, May 29). Why employee turnover is limiting your company's profitability. [Web log post]. Retrieved from:

https://www.chequed.com/blog/why-employee-turnover-is-limiting-your-companys-profitabil ity/

Pay and Benefits. (2014) Burnout found to be a cause of absenteeism. Retrieved from: http://www.payandbenefitsmagazine.co.uk/pab/article/burnout-found-to-be-a-cause-of-absent eeism-12349131

Pianegonda, E. (2014, November 30). Public service sees increase in bullying, absenteeism, according to new report. Retrieved from:

http://www.abc.net.au/news/2014-12-01/public-service-sees-increase-in-bullying-and-absente eism/5930282

Programs for Parents, Inc. (2011). Why should employers take an active role in childcare? It's good business! Retrieved from: http://www.programsforparents.net/businesses

Robert Half. (2015). Exit signs-how to spot an employee on the job hunt. Retrieved from: http://www.roberthalf.com.au/portal/site/rh-au/menuitem.b0a52206b89cee97e7dfed10c3809f a0/?vgnextoid=fbe3ce7ea3240210VgnVCM1000005e80fd0aRCRD

Roberts, J. (2015). Caring for aging parents affects worker absenteeism and productivity. Inside Indiana Business. Retrieved from:

https://www.insideindianabusiness.com/contributors.asp?id=1633

Scott, D., Markham, S., \& Robers, R. (1985). Rewarding Good Attendance: A Comparative Study of Positive Ways to Reduce Absenteeism. Personnel Administrator, 30(8), 72-83, Retrieved from Loyola eCommons, School of Business: Faculty Publications and Other Works.

Slide, C. (2015). 15 tips to deal with employee burnout as a manager or business owner. 


\section{Macrothink}

Business and Economic Research

ISSN 2162-4860

2018, Vol. 8, No. 1

Retrieved from:

http://www.moneycrashers.com/tips-deal-employee-burnout-manager-business/

Stillman, J. (2014, May 16). Happiness won't stop employees from job hunting. Inc. Retrieved from:

http://www.inc.com/jessica-stillman/employee-happiness-does-not-equal-loyalty.html

Substance Abuse and Mental Health Services Administration, Office of Applied Studies. (2007). The NSDUH report: Depression among adults employed full-time, by occupational category. Retrieved from: http://www.oas.samhsa.gov/2k7/depression/occupation.htm

Synerion Workforce Management Solutions. (2015, January 2). The cost of absenteeism in the workplace. [Web log post]. Retrieved from:

http://blog.synerion.com/the-cost-of-absenteeism-in-the-workplace

T. Corbell. (2015, January). 13 management tips to solve employee absenteeism. [Web log post]. Retrieved from: http://www.bizcoachinfo.com/archives/11419

The causes and costs of absenteeism in the workplace. (2013, July 10). Forbes. Retrieved from:

http://www.forbes.com/sites/investopedia/2013/07/10/the-causes-and-costs-of-absenteeism-in -the-workplace/

The Skills Portal. (2013, November 5). Are wellness programmes the cure for employee absenteeism? [Web log post]. Retrieved from:

http://www.skillsportal.co.za/content/are-wellness-programmes-cure-employee-absenteeism

Wellworks For You. (2015). What is the average cost of absenteeism? Retrieved from: http://www.wellworksforyou.com/faq/what-is-the-average-cost-of-absenteeism/

White, C. G. (2001). Reduction of illness absenteeism in elementary schools using an alcohol-free instant hand sanitizer. Journal of School Nursing 17(5), 248-265.

doi.org/10.1177/10598405010170050401

Winmark Corporation. (2015). Tracking absences. Retrieved from:

http://www.wbsonline.com/resources/tracking-absences/

Wojcicki, S. (2014, December 16). Paid maternity leave is good for business. The Wall Street Journal. Retrieved from:

http://www.wsj.com/articles/susan-wojcicki-paid-maternity-leave-is-good-for-business-14187 73756

Woldt, V. (2015). Solving employee eldercare challenges. Retrieved from: http://www.corporateeldercaresolutions.com/articles/Thesis\%20White\%20Paper.pdf

Wolters Kluwer. (2015). Survey says unscheduled absence costs employers 8.7 percent of payroll. Retrieved from:

http://www.employmentlawdaily.com/index.php/news/survey-says-unscheduled-absence-cost s-employers-8-7-percent-of-payroll/ 


\section{Copyright Disclaimer}

Copyright for this article is retained by the author(s), with first publication rights granted to the journal.

This is an open-access article distributed under the terms and conditions of the Creative Commons Attribution license (http://creativecommons.org/licenses/by/3.0/). 